\title{
Surtsey and Mount St. Helens: a comparison of early succession rates
}

\author{
R. del Moral ${ }^{1}$ and B. Magnússon ${ }^{2}$ \\ ${ }^{1}$ Department of Biology, University of Washington, Seattle, Washington 98195, USA \\ ${ }^{2}$ Icelandic Institute of Natural History, Urriðaholtsstræti 6-8, P.O. Box 125, 220 Garðabær, Iceland \\ Correspondence to: R. del Moral (moral@uw.edu)
}

Received: 9 October 2013 - Published in Biogeosciences Discuss.: 10 December 2013

Revised: 12 February 2014 - Accepted: 23 February 2014 - Published: 14 April 2014

\begin{abstract}
Surtsey and Mount St. Helens are celebrated but very different volcanoes. Permanent plots allow for comparisons that reveal mechanisms that control succession and its rate and suggest general principles. We estimated rates from structure development, species composition using detrended correspondence analysis (DCA), changes in Euclidean distance (ED) of DCA vectors, and by principal components analysis (PCA) of DCA. On Surtsey, rates determined from DCA trajectory analyses decreased as follows: gull colony on lava with sand $>$ gull colony on lava, no sand $\gg$ lava with sand $>$ sand spit $>$ block lava $>$ tephra. On Mount St. Helens, plots on lahar deposits near woodlands were best developed. The succession rates of open meadows declined as follows: Lupinus-dominated pumice $>$ protected ridge with Lupinus $>$ other pumice and blasted sites $>$ isolated lahar meadows $>$ barren plain. Despite the prominent contrasts between the volcanoes, we found several common themes. Isolation restricted the number of colonists on Surtsey and to a lesser degree on Mount St. Helens. Nutrient input from outside the system was crucial. On Surtsey, seabirds fashioned very fertile substrates, while on Mount St. Helens wind brought a sparse nutrient rain, then Lupinus enhanced fertility to promote succession. Environmental stress limits succession in both cases. On Surtsey, bare lava, compacted tephra and infertile sands restrict development. On Mount St. Helens, exposure to wind and infertility slow succession.
\end{abstract}

\section{Introduction}

Surtsey (Iceland) volcano emerged from the North Atlantic Ocean in 1963 and continued to erupt until 1967 (Fig. 1a).
Mount St. Helens erupted in 1980 to create large expanses of barren terrain (Fig. 1b). These young volcanoes differ significantly (e.g., isolation and climate), yet each captured the imagination of scientists and the public alike (Friðriksson, 1975, 2005; del Moral and Grishin, 1999). Comparing plant succession in such contrasting habitats allows us to explore factors that control development on barren habitats. The rate of succession can measure the capacity of a site to support integrated communities. Understanding how rates are governed on extreme materials allows for a better understanding of ecosystem interactions (Walker and del Moral, 2009).

Young volcanoes provide ideal conditions to study succession (del Moral, 2009). The rate of primary succession is slow where constrained by stressful conditions and isolation (Walker and del Moral, 2003) because few propagules arrive and immigrants rarely survive (Wood and del Moral, 1987).

Various methods measure succession rates and species turnover (Anderson, 2007). The time to achieving benchmarks is often used (Munson and Laurenroth, 2012). Turnover based on species presence or absence can be used for longer successional trajectories (Chaideftou et al., 2012), and turnover based on changes in the dominant species provide a good intuitive method (Prach et al., 1993). However, floristic turnover is more comprehensive and is calculated using detrended correspondence analysis (DCA; McCune and Mefford, 2006). Its main virtue is that it is a direct estimate of turnover (Mathews and Endress, 2010). Bossuty et al. (2005) showed that the Euclidean distance (ED) between DCA scores summarizes succession rates well. DCA vectors are sensitive to ephemeral cover changes and to climatic variation, and so principal components analysis (PCA) can effectively smooth and summarize DCA trajectories. 

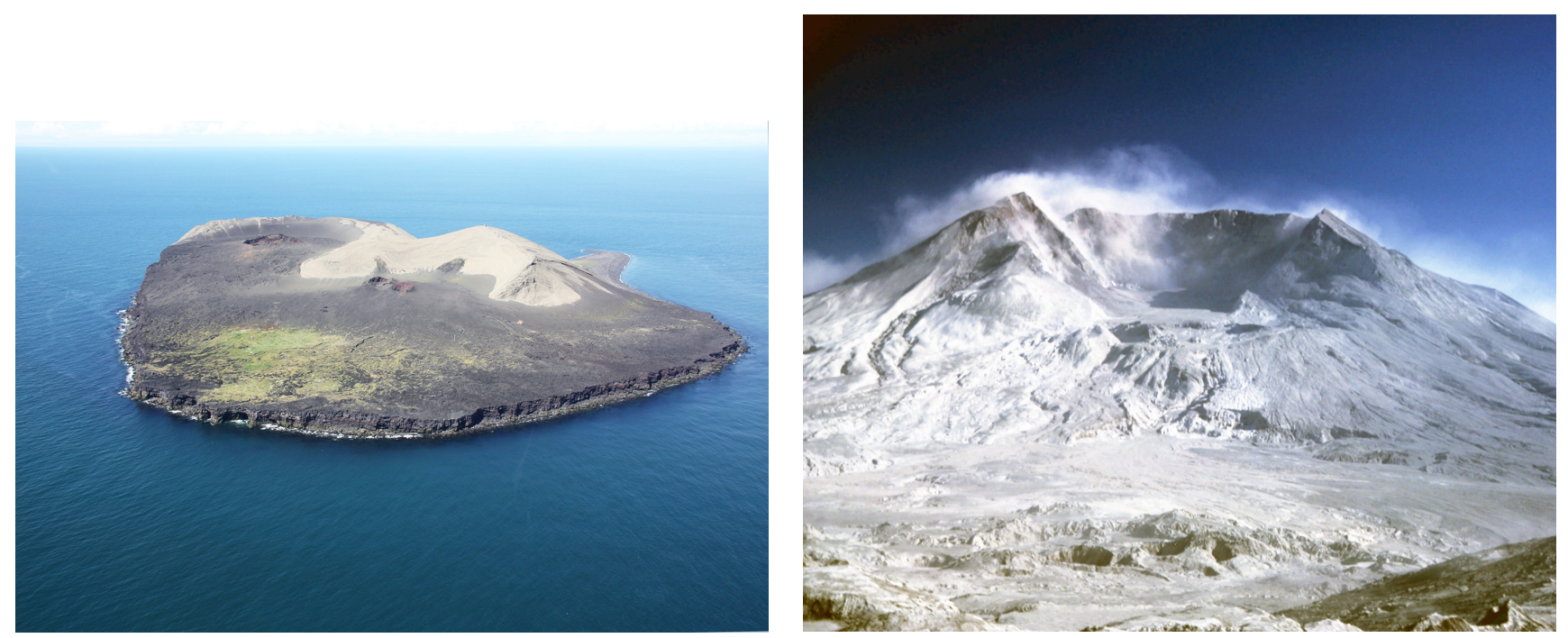

Fig. 1. (A) Surtsey: aerial view looking north showing the barren tephra hills, crater areas and protruding sand spit. The descending lava shield with the dense vegetation of the seabird colony is in the foreground (Photo: Erling Ólafsson, 2010).

(B) Mount St. Helens: aerial view looking south from ca. $15 \mathrm{~km}$ north of the crater overlooking Spirit Lake and showing the devastated habitats (Photo: RdM, August 1980). The Pumice Plain is in the center; Studebaker Ridge is on the extreme right (west) of image.

Here, we compare succession rates on Surtsey to those on Mount St. Helens using two of the most detailed available long-term investigations of biological recovery on volcanoes. What factors are most important in controlling the rate of early primary succession, and do the volcanoes share similar controlling factors? Permanent plots were established on Surtsey in 1990 (Magnússon et al., 1996) and continue to be used. Permanent plots on Mount St. Helens were monitored from 1982 to 2010, inclusive (del Moral, 2010). Direct comparisons should reveal factors that control development in both cases.

\section{Study areas}

The two volcanoes differ in origin, size, location and climate (Table 1), but both are composed of lava, sometimes covered by pumice, sand or tephra. Both support recently established vegetation.

\subsection{Surtsey}

Surtsey emerged from the roiling North Atlantic Ocean on 14 November 1963 and by June 1967 it had reached $155 \mathrm{~m}$ in elevation and occupied $2.7 \mathrm{~km}^{2}$. Erosion had diminished it to about $1.4 \mathrm{~km}^{2}$ (Thórarinsson, 1967; Jakobsson et al., 2000, 2009) by 2012. Magnússon et al. (2009) described the vegetation using 25 permanent plots. Their analyses suggested that dispersal limited species richness, as well as fertility, governed the degree of development. Vegetation within seabird colonies (Fig. 2) was substantial, while lava or tephra sites had changed little (Fig. 3). Until 1974, only beaches had
Table 1. General features of Surtsey and Mount St. Helens.

\begin{tabular}{llll}
\hline Characteristics & Surtsey $^{1}$ & $\begin{array}{l}\text { Mount } \\
\text { St. Helens }\end{array}$ & Comments \\
\hline Surface age & Since 1963 & Since 1980 & \\
Area & $1.4 \mathrm{~km}^{2}$ & $370 \mathrm{~km}^{2}$ & Blast zone \\
Elevation & $155 \mathrm{~m}$ & $2550 \mathrm{~m}$ & To summit \\
Latitude & $63^{\circ} 18^{\prime} \mathrm{N}$ & $46^{\circ} 11^{\prime} \mathrm{N}$ & \\
Longitude & $20^{\circ} 36^{\prime} \mathrm{W}$ & $122^{\circ} 12^{\prime} \mathrm{W}$ & \\
Number of plots & 25 & 49 & Primary sites \\
All vascular plants & 58 & 91 & \\
Reproductive & 39 & 91 & \\
Sampled in plots & 22 & 58 & \\
\hline${ }^{1}$ Status in 2012; ${ }^{2}$ Uplands. & & &
\end{tabular}

much vascular plant vegetation (Fig. 4); as gulls began to nest in some upland sites, vegetation expanded. From 1985 to 1994, seabird abundance increased, mycorrhizal fungi developed (Greipsson and El-Mayas, 2000) and the amount of vegetation in the nesting area exploded (Fig. 5). Since then, the meadow has expanded gradually and its complexity increased. Magnússon et al. (2009) described colonization patterns and noted that ocean currents brought the first colonists to the shores (9\% of the current flora), while wind dispersal brought $16 \%$ of the flora and birds introduced the remaining $75 \%$.

\subsection{Mount St. Helens}

Swanson and Major (2005) detailed the 18 May 1980 eruption and its aftermath. The collapse of the north face 


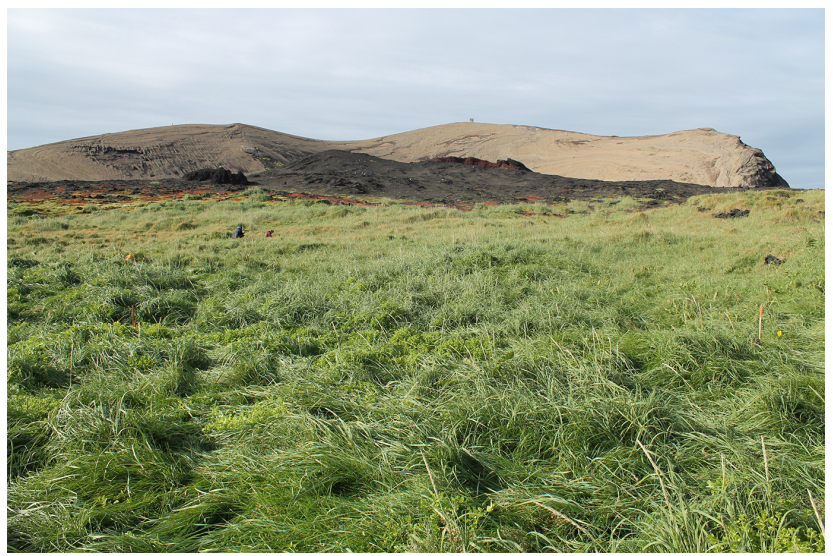

Fig. 2. Surtsey seabird colony with dense grass-dominated vegetation (Photo: BM 2013).

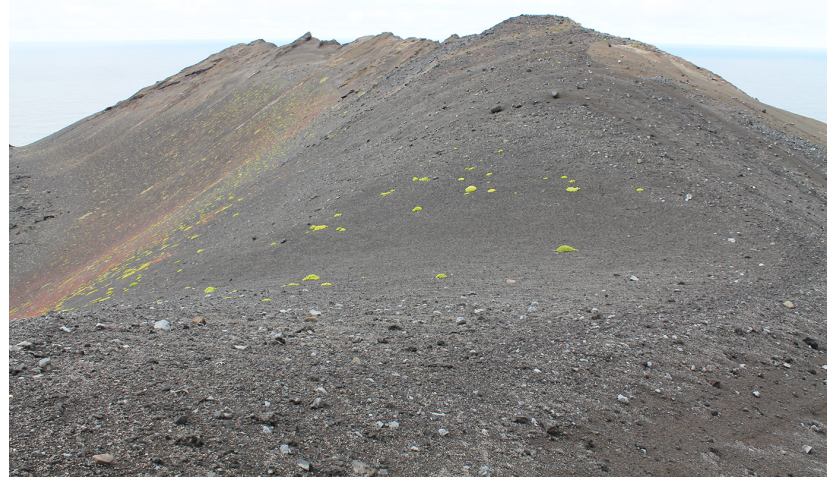

Fig. 3. Surtsey tephra slopes with scattered flowering plants (Photo: BM 2013).

unleashed a mammoth landslide; the ensuing lateral eruption and pyroclastic flows devastated $370 \mathrm{~km}^{2}$ and eliminated $400 \mathrm{~m}$ from the cone. Four habitats once devoid of vegetation were sampled. One lahar deposit on the south side of the cone was adjacent to an intact conifer forest (two plots, Fig. 6); the other was $300 \mathrm{~m}$ from woodlands (five plots, Fig. 7). The Pumice Plain (12 plots) dominates the north flank (Fig. 8), where the blast removed vegetation and soil and deep, coarse pumice was deposited (del Moral et al., 2012). Studebaker Ridge (20 plots), along the western edge of the Pumice Plain, leads to the crater (Fig. 9; del Moral, 2007). The level site on the east flank of the cone (Plains of Abraham) was blasted in the first minutes of the eruption; a broad lahar completed the devastation, then pumice rained down to produce as desolate a landscape as can be imagined (10 plots; Fig. 10, Fig. 11; del Moral et al., 2010). With the exception of Lupinus lep$i d u s$, colonists were wind dispersed (Fuller and del Moral, 2003).

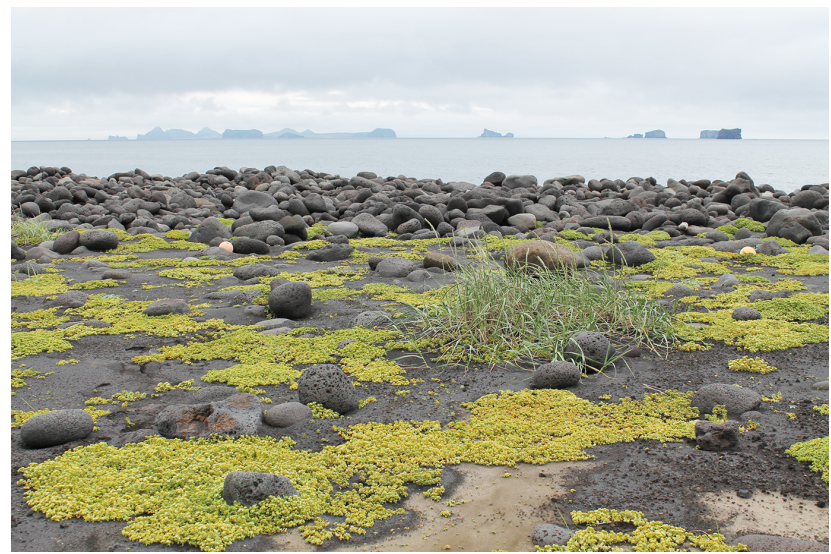

Fig. 4. Shoreline vegetation on the north sand spit of Surtsey (Photo: BM 2013).

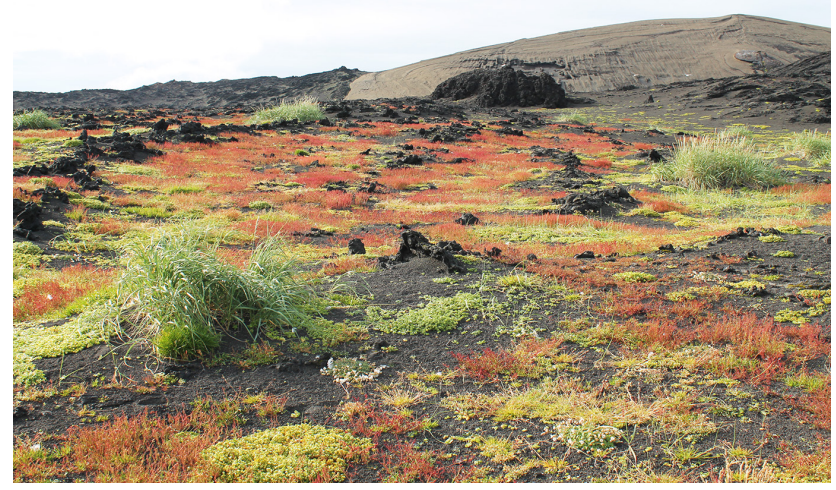

Fig. 5. Pioneer vegetation at the edge of the Surtsey gull colony (Photo: BM 2013).

\section{Methods}

\subsection{Sampling}

Permanent plot sampling on Surtsey started in 1990, with plots added as vegetation developed. Plots are $10 \mathrm{~m} \times 10 \mathrm{~m}$ in size; they sample barren sheet lava, sheet lava covered by sand, block lava, hillside lava covered by tephra and coastal sand. Repeat sampling of the 25 surviving plots (Magnússon and Magnússon, 2000) occurs in July of alternate years, using five parallel, $10 \mathrm{~m}$ long intercept transects to produce percentage cover estimates; species not encountered on the transect, but present in the plot, were given a cover of $0.02 \%$.

At least one plot from each habitat with significant vegetation change is highlighted here to represent typical responses, but all were analyzed (Figs. 12a-15a). Gull colony plots occur on sheet lava, with or without sand deposits. The nine plots on sandy sheet lava that lacked seabird impacts were floristically distinct. There were two plots on tephra-covered lava. These have very little vegetation other than Honckenya. 


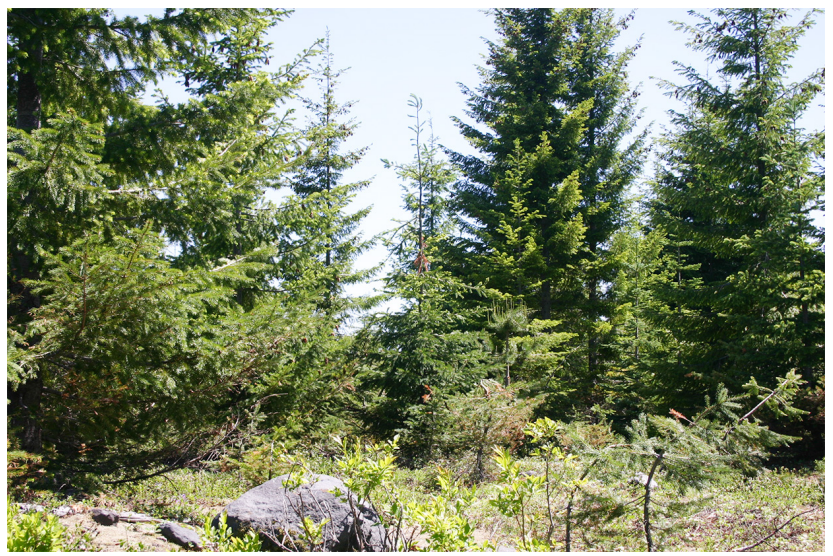

Fig. 6. Lower lahar on the south side of Mount St. Helens, adjacent to woodland, with strong invasion by Abies and Pinus evident (Photo: RdM 2008).

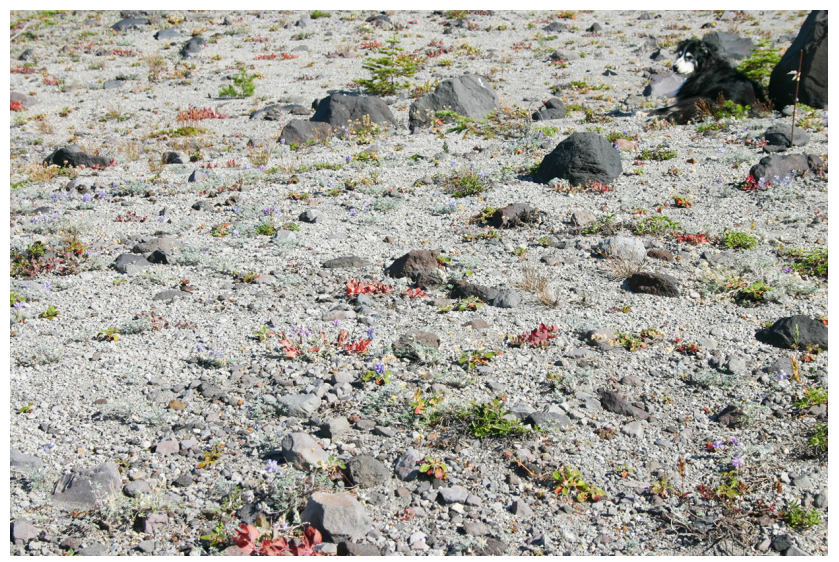

Fig. 7. Lahar deposit vegetation isolated from surviving vegetation (Photo: RdM 2004).

Two plots on the sand spit also were dominated by Honckenya and other sea-dispersed species. Finally, two plots on block lava were established in 2008. Cover is low and vegetation has changed little.

The 49 permanent plots from Mount St. Helens were circular, with a $9 \mathrm{~m}$ radius (i.e., $250 \mathrm{~m}^{2}$ in area). From the center of a plot, four radial transects were each sampled by six $25 \mathrm{~cm} \times 25 \mathrm{~cm}$ quadrats, placed at $1 \mathrm{~m}$ intervals (del Moral, 2010). The percentage cover of each species was recorded in each quadrat. In each plot, species not found in a quadrat were given a score of $0.1 \%$. All plots were analyzed by DCA, but only representative plots are discussed in this study.

\subsection{Statistical analyses}

Richness (number of species) and mean percentage cover per plot in each year were used to assess community development rates as the time needed for richness and cover to reach $90 \%$ of the maximum. Richness loses utility to assess suc-

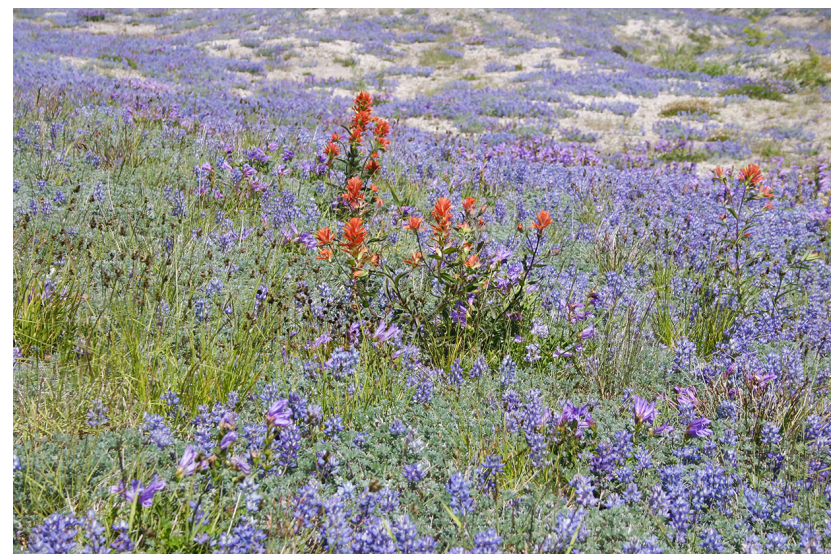

Fig. 8. Upper Pumice Plain plots showing a bloom of Lupinus lepidus with Castilleja miniata (Photo: RdM 2007).

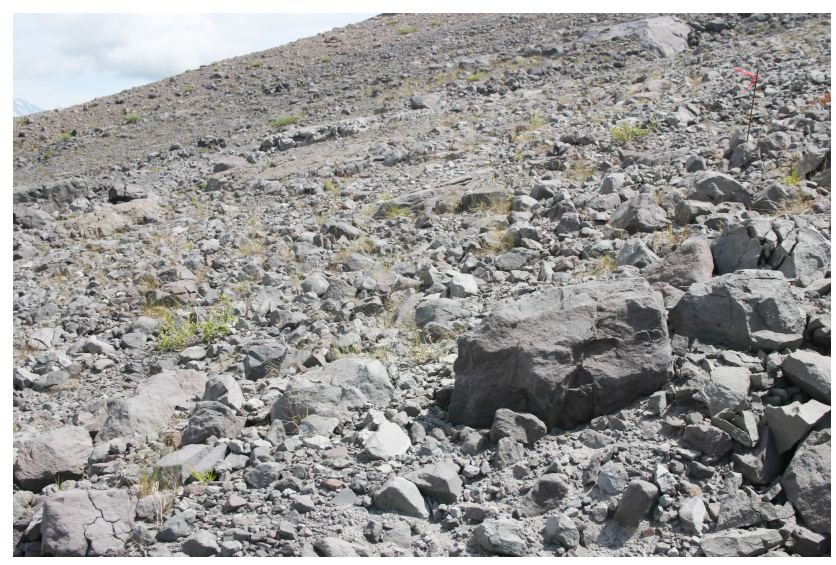

Fig. 9. Upper Studebaker Ridge, with rocky lava exposed and only a few scattered herbs (Photo: RdM 2009).

cession rates once it ceases to increase, although composition continues to change; later in succession, richness may again be useful, particularly when strong dominance reduces richness. Cover ceases to be a good estimate of rates once vegetation becomes dense, but it is a useful during early stages (Baasch et al., 2012).

We used DCA to analyze each data set. Succession rates were determined by changes in DCA scores using ED weighted by the eigenvalue of each axis. Comparisons were between early and late DCA scores and between scores over the last 10 years of the study. ED was divided by the number of years since the surface was established ( 45 or 30 years) to estimate overall rate of floristic change. The ED between successive years was regressed with time to assess changes in succession rate.

Succession trajectories are rarely smooth. Therefore, we used PCA on the first three DCA axes to estimate rates of change in the trajectories, estimated by the slope of the regression with time. Several factors, including large annual fluctuations and nonlinear responses, can limit the value of 


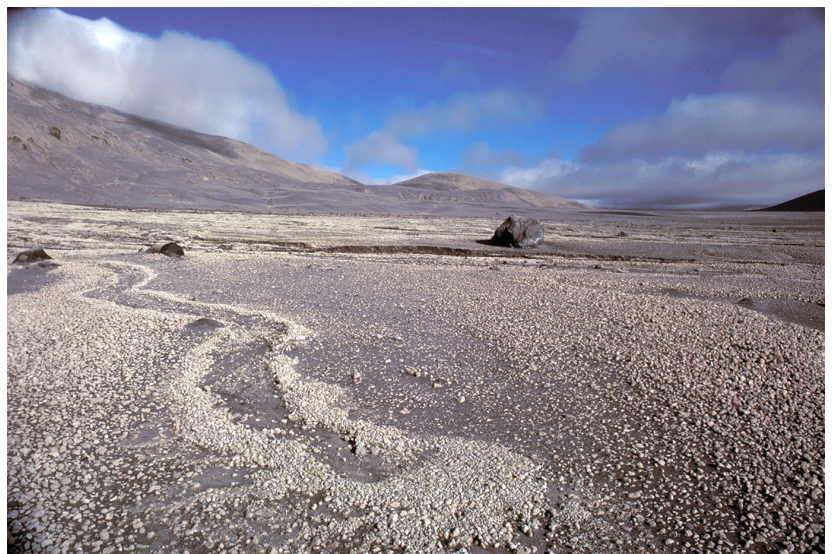

Fig. 10. Plains of Abraham showing total lack of vegetation (Photo: RdM September 1980).

this method. The differences between first and last PCA scores imply the degree of change, and comparisons within a study provide relative succession rates. Only general comparisons between these volcanoes can be made because the number of species differs and it is difficult to account for the effects of different initial sampling dates relative to the initiating event.

Vegetation structure and ordinations were calculated using PC-ORD (McCune and Mefford, 2006), statistics were calculated using Statistix 9 (Analytical Software, 2008) and graphs were produced using Axum 7 (Mathsoft, 2001).

\section{Results}

\subsection{Vegetation composition}

The representative Surtsey plots differed in habitat, fertility and species composition (Table 2). Four occur within the gull colony. Sur-01 is the densest, dominated by three rhizomatous grass genera, Poa, Festuca and Leymus. Each of the three plots reported in this habitat have very high cover and have undergone significant successional change. In 2012, these plots had 6 to 11 species and vegetation cover exceeded $80 \%$. Three plots represent lava with sand, but unaffected by seabirds. These are dominated by Honckenya and Leymus, but are less diverse (3-7 species) with limited cover (1.9$4.0 \%)$.

The sand spit is represented by one plot having four species and modest cover (38\%). These plots suffer frequent disturbances from high waves and unstable substrates that can arrest their development. Although sampling did not start until 2005, this habitat received the first colonists. It is an open community of scattered Honckenya, Mertensia, Leymus and Cakile with moderate cover. The tephra-covered lavas of the island remain sparsely vegetated (3.6\% cover), with few species. Honckenya is the dominant species. Limited nutri-

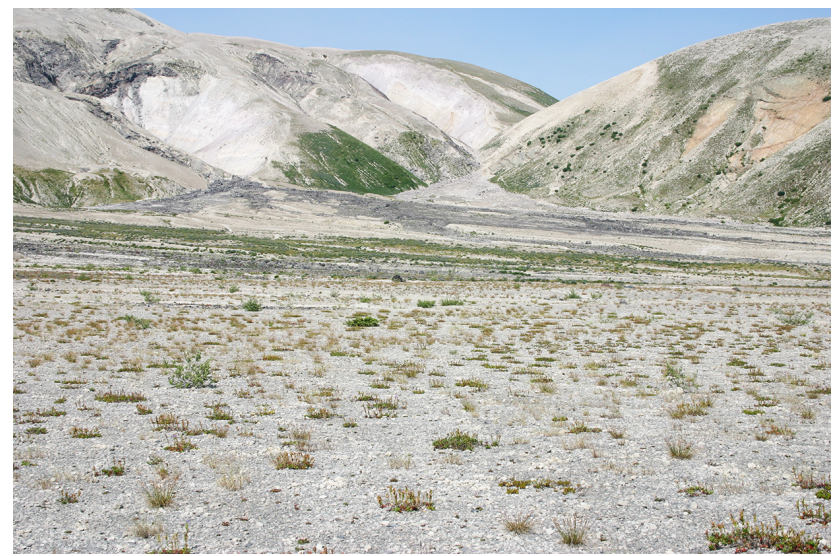

Fig. 11. Plains of Abraham showing very sparse vegetation (Photo: RdM August 2009).

ents and unstable substrates have combined to restrict development. Vascular plants on bare block lava are sparse $(0.1 \%$ cover), although six species occur. This habitat changed little during monitoring.

Eight plots represent the four habitats of Mount St. Helens (Table 3). Richness on proximate lahar deposits reached 25 species per plot, but then declined to 18 species. Isolated lahar plots stabilized at 17 species. Cover was higher in the proximate plots than in the isolated ones. Four low-elevation Pumice Plain plots had modest richness and cover. The three intermediate plots had 18 to 21 species and cover that ranged from 33.0 to $42.2 \%$. The three protected upper plots had similar species richness but higher cover. Cover variation was due largely to Lupinus. The four lower Studebaker Ridge plots had high cover. At higher elevations, four plots had 12 to 15 species, with cover ranging from 5.8 to $9.3 \%$. The upper plots had 13 to 20 species, with low cover (3.6 to $6.5 \%$ ). The Plains of Abraham sample was homogeneous. Differences in species richness were due to rare species, and cover remained sparse.

\subsection{Vegetation structure}

Habitats on Surtsey began to receive species very slowly with only 15 species on the island in 1986 . Once seabirds began to nest, the number of plant species grew rapidly. Plots in the bird colony had only two species when sampling began (Fig. 12a), but by 1994, richness had increased substantially. All other plots studied, except sandy lava sites, had low richness when sampling started. Most increased over a decade and have stabilized. Sandy upland habitats have changed little. Sur-7 demonstrates an interesting pattern. Early in the study, pioneer species dominated. Coincident with increased fertility, species composition shifted towards perennial grasses (e.g., Poa and Festuca), leading to the exclusion of colonizers (Magnússon et al, 2009). Tephra and barren lava sites changed little. While plots in gull colony 
Table 2. Characteristics of selected sample plots on Surtsey. Richness and cover were recorded in 2012. Group richness range is the range of maximum richness. ED is the Euclidean distance of the trajectory; $\triangle \mathrm{PCA}$ is change in PCA-1 scores that summarize the DCA analysis; significant linear regressions indicated as follows: $\alpha=P<0.05 ; \beta=P<0.01 ; \gamma=<0.001$.

\begin{tabular}{llrrrrl}
\hline Habitat & Gulls & Richness & Cover $(\%)$ & ED & $\Delta_{\text {PCA }}{ }^{1}$ & Leading dominants $^{1}$ \\
\hline Sandy sheet lava (Sur-1) & Dense & 7 & 132.3 & 210 & 1.55 & Poapra; Leyare; Fesric; Stemed; Honpep; Cerfon \\
Sheet lava (Sur-7) & Dense & 6 & 94 & 94 & 2.64 & Poapra; Fesric; Cerfon; Sagpro \\
Sheet lava (Sur-9) & Dense & 10 & 68.2 & 48 & 1.54 & Pucdis; Poapra; Matmar; Sagpro; Cerfon; Cocoff \\
Sheet lava (Sur-23) & Moderate & 8 & 14.3 & 59 & 0.98 & Poaann; Pucdis; Sagpro; Cerfon; Fesric; Honpep \\
Gull colony $(n=10)$ & & $\mathbf{3 - 1 2}$ & $\mathbf{4 . 8}-\mathbf{- 1 4 6}$ & $\mathbf{1 5 8}$ & $\mathbf{1 . 3 9}$ & \\
Sandy sheet lava (Sur-13) & No & 3 & 2.3 & $79 \gamma$ & 0.19 & Honpep; Leyare; Sagpro \\
Sandy sheet lava (Sur-16) & No & 5 & 2.9 & 170 & 0.84 & Leyare; Honpep; Sagpro; Cerfon; Siluni \\
Sandy sheet lava (Sur-20) & No & 7 & 4 & $11^{\beta}$ & 0.13 & Honpep; Siluni; Rumace; Cerfon; \\
Sandy sheet lava $(n=8)$ & & $\mathbf{2 - 9}$ & $\mathbf{0 . 5}-\mathbf{2 3 . 8}$ & $\mathbf{5 2}$ & $\mathbf{0 . 3 9}$ & \\
Sand spit (Sur-30) & No & 3 & 38.0 & 1.2 & 0.03 & Honpep; Mermar; Leyare \\
Sand spit $(n=2)$ & & $\mathbf{3}$ & $\mathbf{2 4 . 6 - 3 8 . 0}$ & $\mathbf{0 . 6}$ & $\mathbf{0 . 0 1}$ & \\
Tephra (Sur-15) & No & 2 & 3.6 & 0.7 & 0.02 & Honpep \\
Tephra slope $(n=2)$ & & $\mathbf{2 - 5}$ & $\mathbf{1 . 5}-\mathbf{3 . 6}$ & $\mathbf{4 . 5}$ & $\mathbf{0 . 0 7}$ & \\
Block lava (Sur-31) & No & 6 & 0.18 & 33 & 0.48 & Sagpro; Pucdis; Honpep; Leyare; Poaann; Siluni \\
Block lava $(n=2)$ & & $\mathbf{1 - 6}$ & $\mathbf{0 . 0 2 - 0 . 1 8}$ & $\mathbf{5 2}$ & $\mathbf{0 . 5 3}$ & \\
\hline
\end{tabular}

${ }^{1}$ Species listed in order of dominance in last three years of plots sampled (see Appendix A).

2 Not plotted.

Table 3. Characteristics of sample plots on Mount St. Helens. Richness and cover were the last values recorded. Group richness range is the range of maximum richness. ED and $\triangle \mathrm{PCA}$ are as described in Table 2.

\begin{tabular}{|c|c|c|c|c|c|c|}
\hline Habitat & Impact Type & Richness & Cover $(\%)$ & ED & $\Delta \mathrm{PC}$ & Leading dominants ${ }^{1}$ \\
\hline Lahar 2 - near conifers & Lahar deposit & 18 & 53.1 & $172^{\gamma}$ & 2.36 & Abilas; Pincon; Luepec; Eripyr; Poldav \\
\hline Near woodland range & 2 plots & 18-18 & $53.1-57.2$ & 17 & 3.12 & \\
\hline Lahar 5 - isolated & Lahar deposit & 14 & 13.9 & 98 & 1.57 & Luplep; Eripyr; Pencar; Poldav; Junpar \\
\hline Isolated range & 5 plots & 14-18 & $9.5-22.9$ & 74 & 0.97 & \\
\hline Pumice Plain 3 - low & Blast, pumice & 14 & 11.3 & 124 & 1.51 & Pencar; Luplep; Agrpal; Carmer; Luzpar \\
\hline Low elevation & 4 plots & 14-19 & $11.3-22.0$ & 92 & 1.47 & \\
\hline Pumice Plain 11 - high & Blast, pumice & 20 & 42.9 & $144^{\gamma}$ & 2.24 & Luplep; Agrpal; Salsit; Pencar \\
\hline High elevation & 3 plots & 16-20 & 42.9-58.8 & 139 & 2.01 & \\
\hline Studebaker Ridge 2 - low & Blast & 17 & 62.4 & $96^{\alpha}$ & 0.19 & Agrpal; Luplep; Pencar; Hiealb \\
\hline Low elevation & 4 plots & 14-18 & $11.3-62.4$ & 117 & 0.67 & \\
\hline Mid elevation & 4 plots & 13-16 & $5.3-9.0$ & 109 & 0.78 & \\
\hline Studebaker Ridge 19 - high & Blast & 13 & 3.6 & $62^{\alpha}$ & 0.86 & Luepec; Agrpal; Cisumb; Luplep; Agrsca \\
\hline High elevation & 4 plots & 13 & $3.6-4.5$ & 74 & 0.62 & \\
\hline Plains of Abraham 1 & Blast, scour & 12 & 4.7 & $79^{\alpha}$ & 2.34 & Pencar; Cisumb; Junpar; Agrpal; Carmer \\
\hline Scour with pumice & 10 plots & 11-22 & $3.8-6.0$ & 52 & 0.58 & \\
\hline
\end{tabular}

${ }^{1}$ Species listed in order of dominance in last three years of plots sampled (see Appendix A).

sites reached $90 \%$ of their species richness by the mid-1990s, most other plots did not stabilize until the late 2000s.

Plots on Mount St. Helens reached species richness equilibrium before the end of the study. Lahar deposits accumulated species quickly (Fig. 12b) and peaked in the mid1990s. Subsequent reductions coincided with the development of conifers. Richness on isolated lahar deposits stabilized at about the same time. Pumice plots were barren for the first decade, but protected sites reached stable richness more quickly than did exposed sites. Protected sites experi- enced several cycles of Lupinus booms that produced fertile conditions and the highest species richness among the Mount St. Helens plots. Species accumulation on Studebaker Ridge slowed with elevation increase, but all Studebaker Ridge plots achieved the $90 \%$ richness criterion by the late 1990s. The stressful Plains of Abraham plots consistently had the lowest species richness. Despite a very late start, most plots achieved the criterion by 1996 to 1998 .

Vegetation cover offers clues to habitat stress (Fig. 13a). Cover on Surtsey began to accelerate only where seabird 

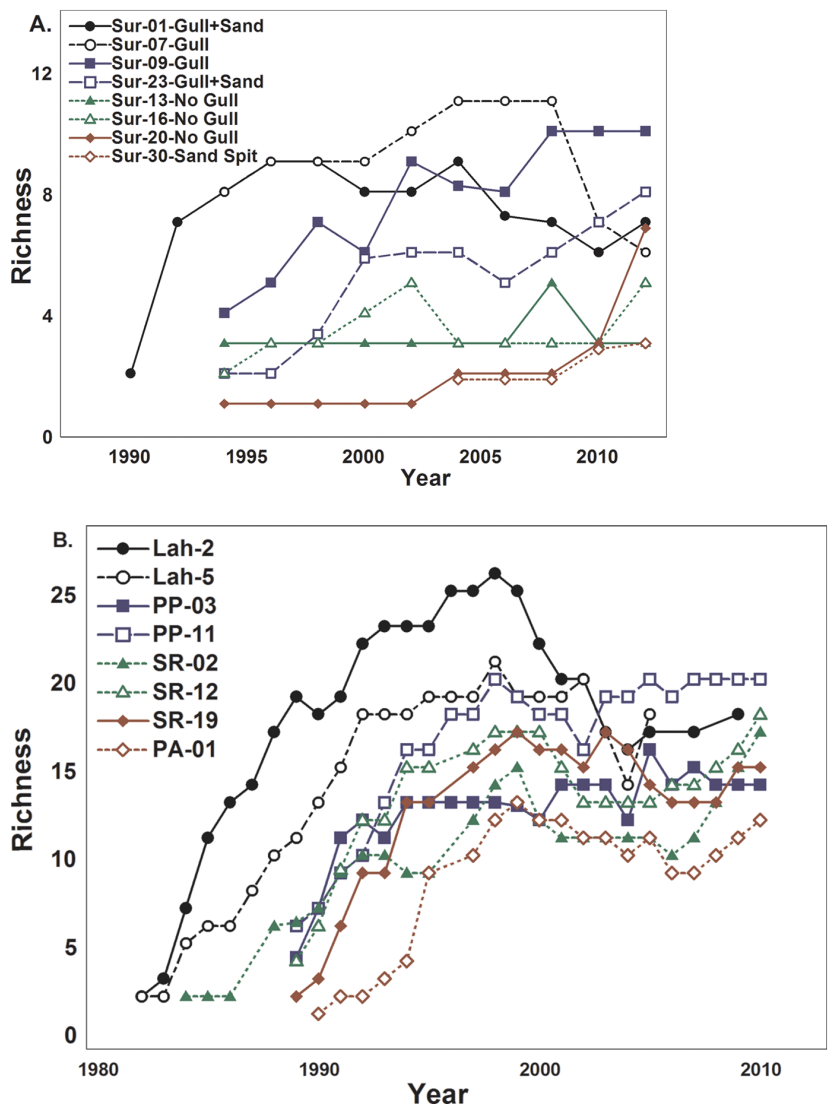

Fig. 12. Richness development on selected plots: (A) Surtsey; (B) Mount St. Helens.

droppings improved fertility. Sur-01 went from about 30 to $120 \%$ between 1990 and 1996 , but only reached the $90 \%$ criterion in 2002. Sur-09 is on lava, which would suggest low cover, but as it is within the gull colony, cover is substantial and peaked in 2010. Lava block plots outside the gull colony, regardless of sand, were barren and unlikely to develop much plant cover in the near future. The cover of coastal sand vegetation (e.g., Sur-30) increased until 2004. It has since stabilized at modest values.

Cover remained low on Mount St. Helens plots for over a decade (Fig. 13b). Cover on proximate lahar deposits began to develop rapidly after 1990 , and the $90 \%$ criterion was reached in 2006. The isolated lahar plots reached this criterion at the same time. Lower pumice plots continued to develop to the end of the study, while the upper plots reached the criterion during the 2007 Lupinus boom. Plots on lower Studebaker Ridge developed slowly for over a decade, but reached the $90 \%$ criterion in the mid-1990s due to Lupinus booms. Upper plots developed more slowly and remain sparse; equilibrium was reached only in the late 2000s. The Plains of Abraham had low cover and reached the $90 \%$ criterion in 2006.
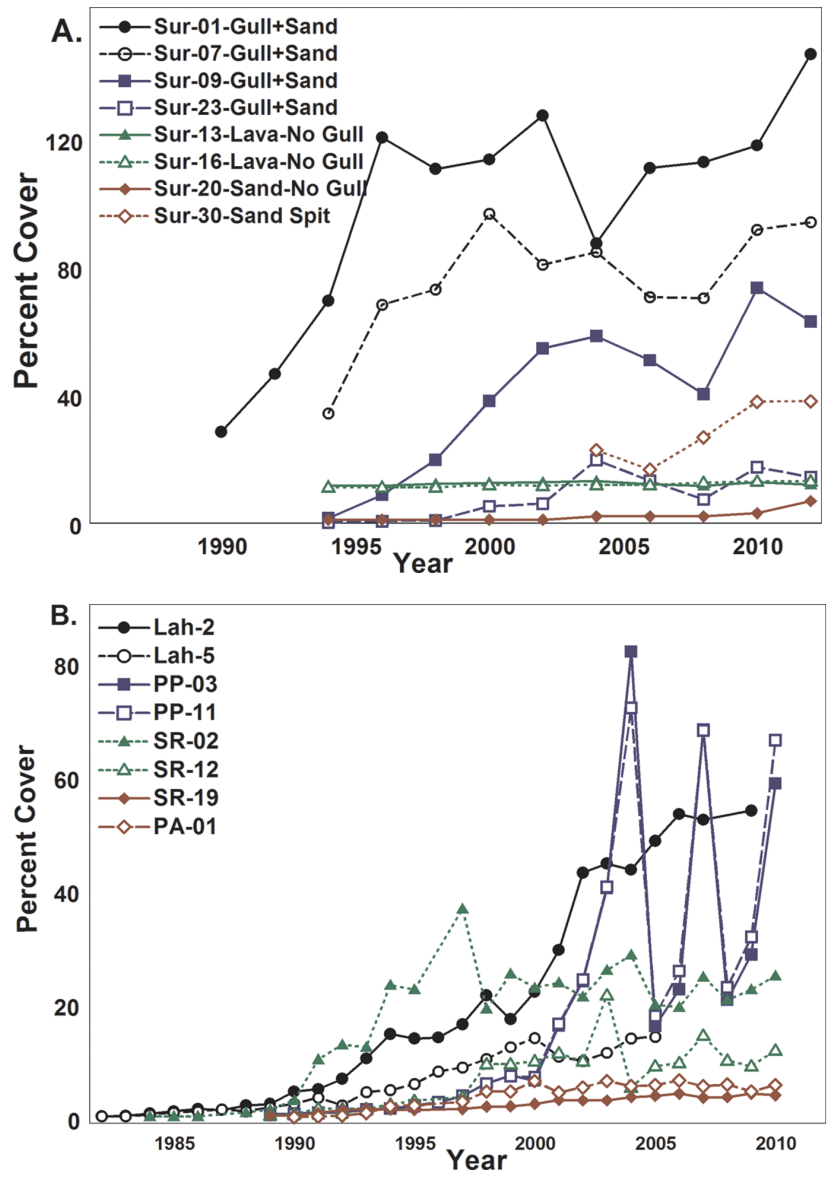

Fig. 13. Percentage cover on selected plots. (A) Surtsey; (B) Mount St. Helens.

\subsection{Floristic trends}

We analyzed vascular plant cover of the 25 plots on Surtsey with DCA to determine succession trajectories. Variation in the first three ordination axes accounted for 18.9, 9.7 and $5.6 \%$ of the total over 3.6, 2.7 and 2.8 half-changes (HC), respectively. We show only four data points for these trajectories to improve legibility; an arrow near the last point shows the direction of each trajectory. The legend indicates the ED traversed by the plot in DCA space, as well as the proportion of this achieved in the last decade.

Vegetation in gull colonies changed greatly compared to that of other lavas (Fig. 14a). Plots dominated by Poa pratensis on sand (Sur-01 and Sur-07) changed the most, while grassy plots on lava (Sur-09) changed substantially. At first, Sur-23 changed little, but as grasses invaded, turnover accelerated. A "horseshoe" trajectory explains why there is a $200 \%$ overall change. Gull colony plots developed more slowly in the last 10 years than did plots in other habitats.

Development in sand-filled sheet lava plots outside gull colonies differed. Sur-13, dominated by Honckenya, changed little at first, but its rate accelerated after 2000. The Leymus 

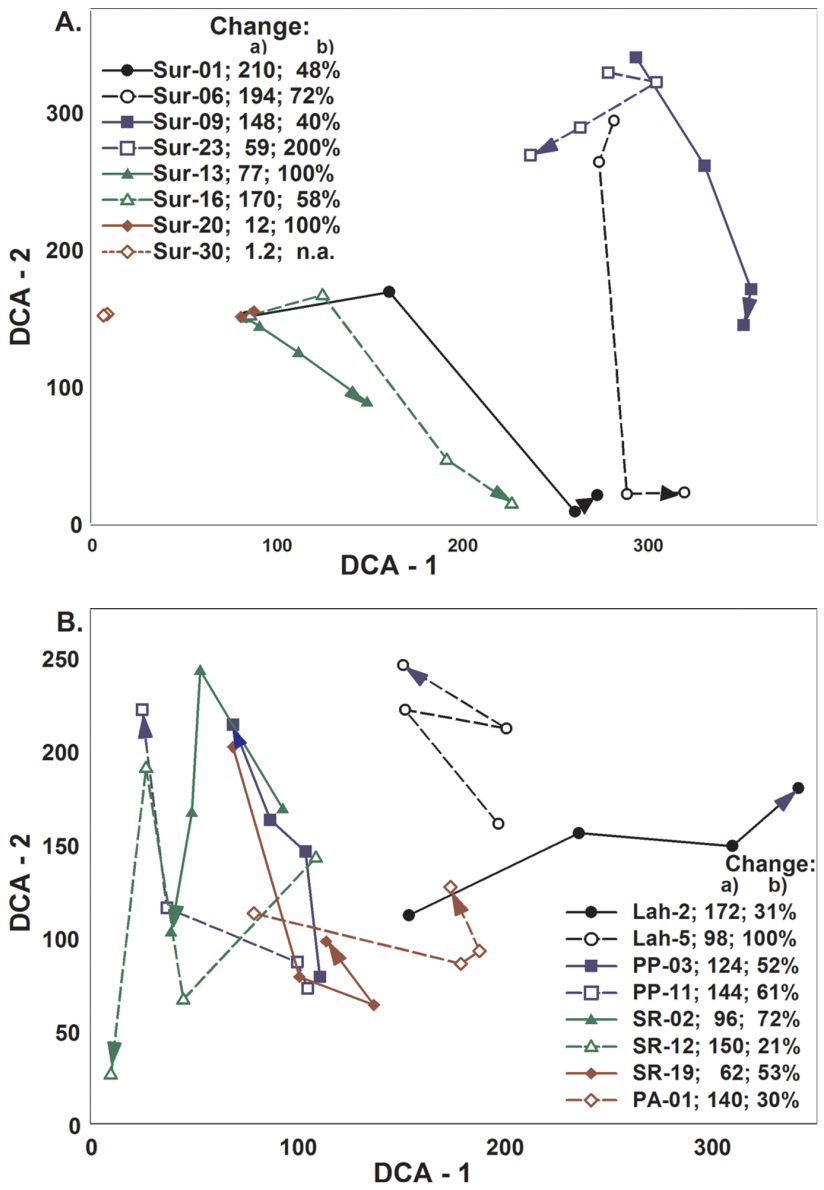

Fig. 14. Modified DCA plots: (A) Surtsey; (B) Mount St. Helens. Change units "a" are the overall Euclidean distance between early and final plots; " $b$ " is the percentage of this change that occurred in the last 10 years of the record. Lower percentages indicate slower development in recent years.

dominated Sur-16 exhibited floristic change comparable to some plots in the gull colony, but its rate of change has slowed. Sur-20 and Sur-30 are difficult to visualize here because both changed little. This was also true of plots on tephra (Sur-15) and block lava (Sur-31, Table 2).

Euclidean distances suggested large changes in the gull colony plots; net change averaged 158 DCA units. The degree of change declined at the margin of the gull colony. Sandy sheet lava lacking seabird inputs experienced about one-third as much floristic change as in the gull colony. Sand spit and tephra plots changed little. The relatively large ED in block lava was due to modest composition changes at low cover. Regression of the PCA changes over time indicated that most seabird sites changed erratically. The rate of change increased in all sand-covered sheet lava lacking seabirds, as it did on the tephra plots. The sand spit and block lava plots changed little.

Sampling on Mount St. Helens began when plots had scant cover. DCA revealed three axes with 18.4, 7.6 and $4.2 \%$ of
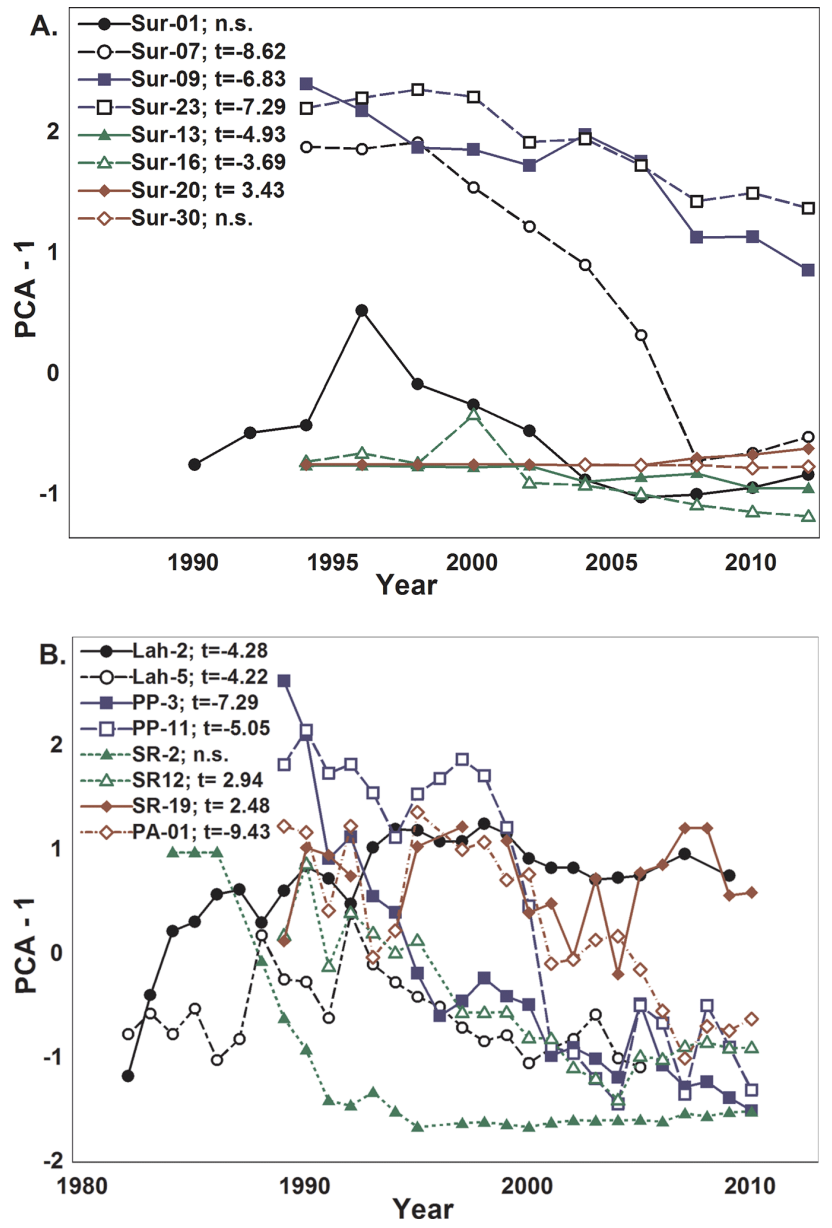

Fig. 15. The first principal component of the DCA scores over time. (A) Surtsey; (B) Mount St. Helens. The $t$ value derives from a linear regression of the PCA 1 axis over time.

the variation, spanning 4.2, 3.0 and $3.5 \mathrm{HC}$. The greatest change occurred on Lah-2, which spanned half of the DCA range. Lah-5 had little overall change. These trajectories diverged as invasion of conifers on Lah-2 directed the vector to the right. The Pumice Plain plots changed at similar rates and diverged slightly. Although PP-11 started slowly, it developed substantially as Lupinus became dominant. The delayed invasion of Lupinus dramatically altered the trajectory of SR-02 and obscured succession rates. SR-12 developed quickly, accumulating pioneer species, but it changed little after 2000. SR-19 changed little. The Plains of Abraham vegetation accumulated species and developed cover slowly.

Succession rate changes, assessed by regression of ED over time, were variable both within and between habitats (Table 3). The succession rates slowed on lahar plots near the forest, while they remained steady on isolated plots. Most plots on the Pumice Plain increased their pace when Lupinus became dominant. The lower Studebaker Ridge plots increased their rate of change or were not significant, while 
upper plots decreased their rate of succession or were not significant. On the Plains of Abraham, rates slowed as persistent species became dominant.

PCA summarized DCA scores and the results were explored by linear regression. Surtsey gull colony plots changed considerably (Fig. 15a). The response of Sur-01 was nonlinear, because from 1990 to 1996, the scores increased (due to Honckenya, Poa апnиa and Cerastium) and then declined (due to Festuca, Leymus and Poa pratensis). After 1996, the regression was significant. Sur-07 and Sur09 scores declined as grasses developed. The PCA trajectory of Sur-23 is similar to the other gull colony plots despite their reduced impact. The changes of the 10 gull colony plots ranged from 0.25 to 2.63 units (average: 1.39 PCA units). Sandy lava plots outside the gull colony changed little. PCA scores of Sur-13 and Sur-16 finished in a cluster with most other plots despite its low cover. Changes were due to the development of Leymus. Sur-20 increased slightly with invasion of forb species. The sand spit plots changed little, perhaps due to chronic disturbance (see Gutzerova and Herben, 2001, for effects of disturbance on succession). The mean PCA change was 0.014 units. Tephra over lava (PCA change of 0.074$)$ and block lava (0.53) also changed little.

PCA changes on Mount St. Helens were larger than in most Surtsey habitats (Fig. 15b). While most trajectories changed significantly, some were curvilinear and thus not linearly significant. Both proximate plots on lahars changed significantly (mean: 3.12 PCA units), while the mean of five isolated lahar plots was 0.97 units. Overall change in lower pumice plots averaged 1.47 PCA units, while those in the upper plots averaged 2.01 units. These changes were the result of strong pulses of Lupinus. Trajectories of several Studebaker Ridge plots were curvilinear (e.g., SR-02). Other lower plots changed more directionally and their average change was 0.67 PCA units. PCA of the Plains of Abraham plots changed little.

\section{Discussion}

Assessing rates of succession is increasingly important in conservation and restoration due to accelerating climate and habitat change that causes rapid shifts in species distributions (Kapfer et al., 2012). Understanding what governs succession rates improves the creation of alternative management procedures (cf. Engel and Abella, 2011). Repeated sampling of permanent plots allows rates to be measured with more confidence than is possible using chronosequences (Feldmeyer-Christe et al., 2011).

\subsection{Succession rates on Surtsey}

All approaches used in this study converge to the conclusion that although dispersal barriers restrict the flora, rates of succession on Surtsey are governed primarily by soil fer- tility. Seabirds import nutrients from the ocean and the gull colony vegetation is now dominated by strongly competitive, nutrient-responsive species (Liancourt et al., 2009). Even by 1992, vascular plant richness and cover in the central colony were low; development in the margins of the colony was even slower. Similar habitats outside of the colony remained poorly developed. Sand spit communities developed slowly, but have achieved modest richness and cover.

The rate of succession can be assessed by several parameters (Table 4). For each, the value of a plot was determined and ranked. By each standard, plots on lava with sand in the gull colony developed structure most rapidly and changed the most during the study.

Gull colony plots on sand developed richness and cover faster than the other plots. Total floristic change was greatest and the $\triangle \mathrm{PCA}$ was similar to that of plots in the gull colony lacking sand. Plots on the margins of the gull colony had delayed development and were intermediate in floristic development. Sheet lava offered more germination sites than did block lava, and so cover development, although slow, was more rapid. Tephra and block lava had so little vegetation that differences were irrelevant. However, block lava plots showed some turnover. The sand spit changed least in terms of flora, but developed substantial cover; thus if succession were to be gauged solely by the accumulation of biomass, this vegetation fares well in comparison to the more stressed communities. However, repeated disturbances appear to hold this vegetation in an arrested state of development because little turnover has occurred.

\subsection{Succession rates on Mount St. Helens}

Rates of succession on Mount St. Helens are less clear than on Surtsey. Alternative methods of assessment give different rankings (Table 5). Time to peak value of richness is a poor method because time is generally short. However, useful patterns exist in the other parameters. Most suggest that the invasion of conifers produced the most rapid succession. The upper pumice plots developed more rapidly than most herb-dominated plots, likely due to the fertility enhancement by Lupinus and more shelter from wind. The lower plots on Studebaker Ridge accumulated species rapidly and cover development was moderately rapid. The succession rate measured by floristic turnover was intermediate. Isolated plots on lahar deposits acquired most of their flora quickly, but cover and floristic turnover were moderate to low. The slowest succession occurred on the wind-swept, isolated and infertile Plains of Abraham.

\subsection{Comparing factors that affect rates}

Succession rates are affected by both external and internal factors. The degree and nature of isolation affect the density, nature and identity of colonists (Bossuyt et al., 2005), while substrate qualities (e.g., fertility, moisture status and 
Table 4. Relative ranking of succession rates on Surtsey using several criteria.

\begin{tabular}{lrrrrrrr}
\hline Habitat & Richness & $\begin{array}{r}\text { Rate to } \\
\text { peak }\end{array}$ & Cover & $\begin{array}{r}\text { Rate to } \\
\text { peak }\end{array}$ & ED & $\begin{array}{r}\Delta \text { PCA } \\
\text { PCA } \\
\text { diff. }\end{array}$ \\
\hline Lava: gull \& Sand & 1 & 1 & 1 & 1 & 1 & 1 & 1.38 \\
Lava: gull & 2 & 1 & 2 & 2 & 2 & 1 & 1.46 \\
Lava: moderate gull & 3 & 2 & 4 & 3 & 3 & 3 & 0.84 \\
Lava: sand & 4 & 3 & 5 & 5 & 4 & 4 & 0.51 \\
Lava: block & 5 & 4 & 7 & 6 & 5 & 5 & 0.43 \\
Tephra & 5 & 4 & 6 & 6 & 6 & 6 & 0.07 \\
Sand spit & 5 & 4 & 3 & 4 & 7 & 7 & 0.01 \\
\hline
\end{tabular}

Table 5. Relative ranking of succession rates on Mount St. Helens using several criteria.

\begin{tabular}{lrrrrrrr}
\hline Habitat & Richness & $\begin{array}{r}\text { Rate to } \\
\text { peak }\end{array}$ & Cover & $\begin{array}{r}\text { Rate to } \\
\text { peak }\end{array}$ & ED & $\begin{array}{r}\Delta \text { PCA } \\
\text { PCA } \\
\text { diff. }\end{array}$ \\
\hline Lahar: Near & 1 & 1 & 1 & 2 & 1 & 1 & 1.97 \\
Lahar: far & 3 & 1 & 4 & 4 & 5 & 3 & 0.63 \\
Pumice: low & 1 & 2 & 3 & 4 & 4 & 2 & 1.49 \\
Pumice: high & 1 & 1 & 1 & 1 & 2 & 1 & 1.70 \\
Blasted ridge: low & 2 & 1 & 2 & 3 & 3 & 2 & 1.00 \\
Blasted ridge: mid & 2 & 2 & 4 & 4 & 3 & 3 & 1.73 \\
Blasted ridge: high & 3 & 2 & 4 & 5 & 4 & 3 & 0.62 \\
Scour: Abraham & 4 & 1 & 5 & 5 & 5 & 4 & 0.52 \\
\hline
\end{tabular}

stability) affect establishment and development of species that pass through the isolation filter. This double filter permits species composition of two similar sites to differ due solely to chance effects (Grime and Pierce, 2012).

The determination of succession rates is complicated by several factors (Walker and del Moral, 2003). Often the rate of succession determined by species turnover was rarely constant. As the vegetation matures, species with greater longevity become dominant. Internal dynamics may be irrelevant to the questions at hand, but they offer insight into mechanisms driving succession. Using only calculations based on starting and ending conditions may miss internal changes. Even simple analyses of fluctuating succession rates can offer insights.

Because Surtsey and Mount St. Helens developed with different levels of diversity, it is inapt to compare their floristic turnover rates. There were 52 species in plots of Mount St. Helens at the end of the study, and 22 species within Surtsey plots in 2012. General comparisons reveal fundamental factors that control the pace of succession.

Cold seawater isolates Surtsey, while subalpine sites on Mount St. Helens have been isolated for millennia, creating a flora much smaller than that of surrounding volcanoes (del Moral and Wood 1988). Few propagules established on Surtsey until the colonization of seabirds, retarding upland succession. On Mount St. Helens, vagile wind-dispersed propagules soon arrived, but sterility and stress severely limited establishment (Wood and del Moral 1987). On Surtsey, colo- nization from fertile sites to the uplands also may be limited by stress and dispersal limitations. On Mount St. Helens, short distances filter the seed rain and affect species composition. In other Mount St. Helens studies, distance from sources of colonists reduced species richness and delayed the development of vegetation (del Moral et al., 2009).

Landscape effects influence the arrival of propagules and are a major influence on the rate of ecosystem change. The delay of development on Surtsey resulted from the restricted dispersal of key plant species to sites made fertile by seabirds. On Mount St. Helens, nutrient input began immediately as a meager but constant input by the wind (Edwards 1987). Deposited insects, spiders, spores, seeds and debris were concentrated in microsites. Aeolian input of nutrients is common, but seldom appreciated (Ingimarsdóttir et al., 2013). Its importance on Surtsey may become progressively more important in the uplands, where nutrient deposition has allowed soil fertility to develop slowly.

Like birds on Surtsey, Lupinus lepidus on Mount St. Helens changed fertility levels dramatically (del Moral and Rozzell, 2005). The most rapid Mount St. Helens trajectories occur where lupines became dominant, while the slowest are on the Plains of Abraham, where lupines remain scarce. The low numbers of birds and mammals and their diffuse distribution limit animal effects on soil fertility compared to the seabirds of Surtsey.

This study did not explore seedling establishment, but the importance of surface characteristics is evident on both 
volcanoes. On Surtsey, sites with sand developed more quickly than barren lava. Sandy substrates provide more opportunities for seeds to escape desiccation and predation (Tsuyuzaki et al., 1997). On Mount St. Helens, microsites were crucial to early seedling establishment (del Moral et al., 2005).

Infertility, instability and isolation combined to constrain succession on much of Surtsey, especially where tephra persists. On Mount St. Helens, tephra was widespread, but nowhere did it obliterate vegetation to initiate primary succession. In other boreal sites, thick isolated tephra deposits retard succession of vascular plants (e.g., Grishin et al., 1996).

The longevity of dominant species affects the rate of succession once vegetation occupies the suitable space. On Surtsey sandy gull colony plots, the succession rate first increased then decreased as grasses dominated. Less developed plots increased their rate of change. On Mount St. Helens, development slowed as woody species came to dominate. Sparsely vegetated plots lacked pattern. Where vegetation was sparse for 15 to 20 years before rapidly accumulating biomass, the pace of succession then accelerated. Because accelerated succession on Mount St. Helens was associated with Lupi$n u s$, it may be that enhancing fertility can accelerate succession. However, excessive fertilization favors a few dominants to retard succession.

\section{Coda}

Surtsey and Mount St. Helens are vividly different, yet the establishment of vegetation on their barren surfaces followed similar principles. On both, isolation retards community development and filters the available species. Stress further filters colonists. This combination of isolation and stress leads to initially variable vegetation. The result is frequently local dominance by different species with similar ecological characteristics. At both locations, the alleviation of stress by physical and biological processes accelerates succession rates, although the mechanisms may differ. Habitat heterogeneity was crucial for the establishment of the first colonists on both volcanoes.

Acknowledgements. R. del Moral thanks the US National Science Foundation for funding (OPUS grant DEB-1118593) and the Mount St. Helens National Volcanic Monument for permission to investigate succession. B. Magnússon thanks the Icelandic Centre for Research for funding the initiation of the study, the Surtsey Research Society for logistic support and the Icelandic Coast Guard for transport to the island.

Edited by: B. D. Sigurdsson

\section{References}

Analytical Software. Statistix 9. Analytical Software, Tallahassee, FL, US, 2008.

Anderson, K. J.: Temporal patterns in rates of community change during succession, Am. Natur., 169, 780-793, 2007.

Baasch, A., Kirmer, A., and Tischew. S.: Nine years of vegetation development in a post-mining site: effects of spontaneous and assisted site recovery, J. Appl. Ecol., 49, 251-260, 2012.

Bossuyt, B., Honnay, O., and Hermy, M.: Evidence for community assembly constraints during succession in dune slack plant communities, Plant Ecol., 178, 201-209, 2005.

Chaideftou, E., Kallimanis, A. S., Bergmeier, E., and Dimopoulos, P.: How does plant species composition change from year to year? A cases study from the herbaceous layer of a subMediterranean oak woodland, Commun. Ecol., 13, 88-96, 2012.

del Moral, R.: Vegetation dynamics in space and time: an example from Mount St. Helens, J. Veg. Sci., 18, 479-488, 2007.

del Moral, R.: Primary succession on Mount St. Helens, with reference to Surtsey, Surtsey Res., 12, 153-157, 2009.

del Moral, R.: Thirty years of permanent vegetation plots, Mount St. Helens, Washington, Ecology, 91, 2185, doi:10.1890/092357.1, 2010.

del Moral, R. and Grishin, S. Y.: The consequences of volcanic eruptions, in: Ecosystems of disturbed ground, edited by: Walker, L. R., 137-160, Elsevier, Amsterdam, 1999.

del Moral, R. and Rozzell, L. R.: Effects of lupines on community structure and species association, Plant Ecol., 180, 203-215, 2005.

del Moral, R. and Wood, D. M.: The high elevation flora of Mount St. Helens, Washington, Madroño, 35, 309-319, 1988.

del Moral, R., Wood, D. M., and Titus, J. H.: How landscape factors affect recovery of vegetation on barren surfaces, in: Mount St. Helens 20 years after recovery, edited by: Dale, V. H., Swanson, F. J., and Crisafulli, C. M., 163-179, Springer, New York, 2005.

del Moral, R., Sandler, J. E., and Muerdter, C. P.: Spatial factors affect primary succession on the Muddy River Lahar, Mount St. Helens, Washington, Plant Ecol., 202, 177-190, 2009.

del Moral, R., Saura, J. M., and Emenegger. J. N.: Primary succession trajectories on a barren plain, Mount St. Helens, Washington, J. Veg. Sci., 21, 857-867, 2010.

del Moral, R., Thomason, L. A., Wenke, A. C., Lozanoff, N., and Abata, M. D.: Primary succession trajectories on pumice at Mount St. Helens, Washington, J. Veg. Sci., 23, 73-85, 2012.

Edwards, J. S.: Arthropods of aeolian systems, Ann. Rev. Entom., 32, 163-179. 1987.

Engel, E. C. and Abella, S. R.: Vegetation recovery in a desert landscape after wildfires: influences of community type, time since fire and contingency effects, J. Appl. Ecol., 48, 1401-1410, 2011.

Feldmeyer-Christe, E., Kuechler, M., and Wildi, O.: Patterns of early succession on bare peat in a Swiss mire after a bog burst, J. Veg. Sci., 22, 943-954, 2011.

Friðriksson, S.: Surtsey. Evolution of life on a volcanic island, Butterworths, London, 1975.

Friðriksson, S.: Surtsey. Ecosystems formed, Varði and The Surtsey Research Society, Reykjavik, 2005.

Fuller, R. N. and del Moral, R.: The role of refugia and dispersal in primary succession on Mount St. Helens, Washington, J. Veg. Sci., 14, 637-644, 2003. 
Greipsson, S. and El-Mayas, H.: Arbuscular mycorrhizae of Leymus arenarius on coastal sands and reclamations sites in Iceland and response to inoculation, Rest. Ecol., 8, 144-150, 2000.

Grime, J. P. and Pierce, S.: The evolutionary strategies that shape ecosystems, Wiley/Blackwell, Chichester, 2012.

Grishin, S. Y., del Moral, R., Krestov, P. V., and Verkholat, V. P.: Succession following the catastrophic eruption of Ksudach volcano (Kamchatka, 1907), Vegetatio, 127, 129-153, 1996.

Gutzerova, N. and Herben, T.: Patch dynamics and local succession in a sandstone area with frequent disturbance, J. Veg. Sci., 12, 533-544, 2001.

Ingimarsdóttir, M., Ripa, J., Magnúsdóttir, Ó. B., and Hedlund, K.: Food web assembly in isolated habitats: A study from recently emerged nunataks, Iceland, Basic Appl. Ecol., 14, 174183,2013

Jakobsson, S. P., Gudmundsson, G., and Moore, J. G.: Geological monitoring of Surtsey, Iceland, 1967-1998, Surtsey Res., 11, 99 108,2000

Jakobsson, S. P., Thors, K., Vesteinsson, Á. T., and Ásbjörnsdóttir, L.: Some aspects of the seafloor morphology at Surtsey volcano: The new multibeam bathymetric survey of 2007, Surtsey Res., 12, 9-20, 2009

Kapfer, J., Virtanen, R., and Grytnes, J.-A.: Changes in arctic vegetation on Jan Mayen Island over 19 and 80 years, J. Veg. Sci., 23, 771-781, 2012.

Liancourt, P., Viard-Cretat, F., and Michalet, R.: Contrasting community responses to fertilization and the role of the competitive ability of dominant species, J. Veg. Sci., 20, 138-147, 2009.

Magnússon, B. and Magnússon, S. H.: Vegetation succession on Surtsey during 1990-1998 under the influence of breeding seabirds, Surtsey Res., 11, 9-20, 2000.

Magnússon, B., Magnússon, S. H., and Guðmundsson, J.: Gróðurframvinda í Surtsey. (Vegetation succession on the volcanic island Surtsey), Icelandic Agr. Sci., 10, 253-272, 1996.

Magnússon, B., Magnússon, S. H., and Friðriksson, S.: Developments in plant colonization and succession on Surtsey during 1999-2008, Surtsey Res., 12, 57-76, 2009.
Mathsoft: Axum 7 for Windows, Insightful Corporation, Seattle, WA, US, 2001.

Matthews, J. W. and Endress, A. G.: 2010. Rate of succession in restored wetlands and the role of site context, Appl. Veg. Sci., 13, 346-355, 2010.

McCune, B. and Mefford, M. J.: PC-ORD, multivariate analysis of ecological data, version 5.0. MjM Software Design, Gleneden Beach, OR, US, 2006.

Munson, S. M. and Laurenroth, W. K.: Plant community recovery following restoration in semiarid grasslands, Rest. Ecol., 20, 656-663, 2012.

Prach, K., Pyšek, P., and Šmilauer, P.: On the rate of succession, Oikos, 66, 343-346, 1993.

Sigurdsson, B. D. and Magnusson, B.: Effects of seagulls on ecosystem respiration, soil nitrogen and vegetation cover on a pristine volcanic island, Surtsey, Iceland, Biogeosciences, 7, 883-891, doi:10.5194/bg-7-883-2010, 2010.

Swanson, F. J. and Major, J. J.: Physical events, environments and geological-ecological interactions at Mount St. Helens: March 1980-2004, in: Mount St. Helens 20 years after recovery, edited by: Dale, V. H., Swanson, F. J., and Crisafulli, C. M., 27-44, Springer, New York, 2005.

Thórarinsson, S.: Surtsey: The new island in the North Atlantic, Viking Press Inc., New York, 1967.

Tsuyuzaki, S., Titus, J. H., and del Moral, R.: Seedling establishment patterns on the Pumice Plain, Mount St. Helens, Washington, J. Veg. Sci., 8, 727-734, 1997.

Walker, L. R. and del Moral, R.: Primary succession and ecosystem rehabilitation, Cambridge University Press, Cambridge, UK, 2003.

Walker, L. R. and del Moral, R.: Transition dynamics in succession: implications for rates, trajectories and restoration, in: New models for ecosystem dynamics and restoration, edited by: Hobbs, R. J. and Suding, K. N., 33-49, Island Press, Washington, US, 2009.

Wood, D. M. and del Moral, R.: Mechanisms of early primary succession in subalpine habitats on Mount St. Helens, Ecology, 68, 780-790, 1987. 


\section{Appendix A}

Table A1. Key to abbreviations used in Tables 2 and 3.

\begin{tabular}{llll}
\hline Abbreviation & Surtsey: Latin name & Abbreviation & Mount St. Helens: Latin name \\
\hline Cerfon & Cerastium fontanum & Abilas & Abies lasiocarpa \\
Cocoff & Cochlearia officinalis & Agrpal & Agrostis pallens \\
Fesric & Festuca richardsonii & Carmer & Carex mertensii \\
Honpep & Honckenya peploides & Cisumb & Cistanthe umbellata \\
Leyare & Leymus arenarius & Eripyr & Eriogonum pyrolifolium \\
Matmar & Matricaria maritima & Hiealb & Hieracium albiflorum \\
Mermar & Mertensia maritima & Junpar & Juncus parryi \\
Poaann & Poa annua & Luepec & Luetkea pectinata \\
Poapra & Poa pratensis & Luplep & Lupinus lepidus \\
Pucdis & Puccinellia distans & Luzpar & Luzula parviflora \\
Rumace & Rumex acetosella & Pencar & Penstemon cardwellii \\
Sagpro & Sagina procumbens & Pincon & Pinus contorta \\
Siluni & Silene uniflora & Poldav & Polygonum davisiae \\
Stemed & Stellaria media & Salsit & Salix sitchensis \\
\hline
\end{tabular}

